\title{
Historical Lessons from Twentieth-Century Pandemics Due to Respiratory Viruses
}

\author{
Eelco F. M. Wijdicks ${ }^{*}$ (D) \\ (c) 2020 Springer Science+Business Media, LLC, part of Springer Nature and Neurocritical Care Society
}

The medical conundrum of pandemics caused by respiratory viruses-novel or mutated-can be of interest to neurointensivists and not only those captivated by history. Rapidly compromised oxygen delivery and the possibility of consequent bacterial infections that may secondarily damage the brain create a potentially urgent situation. Moreover, and for sure in the laboratory, neurotropism of some respiratory viruses has been documented.

Neurocritical care as a specialty has a connection to the poliomyelitis epidemics of the 1950s. In fact, there has been a persistent assertion that the specialty started with the poliomyelitis pandemics, although a more accurate interpretation is that the poliomyelitis pandemics signaled the beginning of intensive respiratory care as a medical discipline. Hospitals were suddenly confronted with a devastating paralysis requiring acute ventilator support. At that time, mechanical ventilation was possible with the so-called iron lung, a tank that incorporated electrically driven blowers resulting in inspiration with negative pressures. During these early days of mechanical ventilation, hospitals throughout the world had few of these respirators available-an eerie familiarity to our current SARS-COVID-19 challenge in 2020!

One solution came from Denmark, where Lassen and Ibsen managed a growing number of admissions of patients with respiratory failure, pharyngeal weakness, and closed airways due to pooling secretions. Tracheostomy and positive-pressure ventilation made caring for patients much easier than a tank or cuirass respirator $[1,2]$.

\footnotetext{
*Correspondence: wijde@mayo.edu

Division of Neurocritical Care and Hospital Neurology, Mayo Clinic, 200

First Street SW, Rochester, MN 55905, USA

This article is part of the collection "Neurocritical Care Through History".
}

Epidemics with potentially lethal respiratory viruses are physiologically different from bellows failure in bulbar forms of poliomyelitis because it involves oxygen transport and much more. These epidemics and pandemics were caused by H1N1, corona viruses (severe acute respiratory syndrome or SARS, Middle East respiratory syndrome or MERS) with patients admitted to intensive care units with acute respiratory distress syndrome and multiorgan failure. In the last three centuries, 12 pandemics have been caused by influenza $A$, with the most iconic known as the 1918 "Spanish flu" pandemic. Between 1933 and 1957, the world experienced nine influenza A (H1N1) epidemics and five influenza B epidemics. The worst of all these later pandemics was the 1935 and 1936 influenza B epidemics, which caused at least 55,000 deaths in USA. An animal corona virus jumped species and caused a worldwide outbreak of nearly 9000 cases of SARS from late 2002 into the summer of 2003. Now, in the middle of one of the worst pandemics due to a novel respiratory virus SARS-COVID-19, we must briefly journey through the past for insights. Three main questions can be asked, and answers may be found in the annals of medical history. First, are some respiratory viruses clinically neurotropic and damaging to the central and peripheral nervous system? Despite a handful of cases, a major neurologic syndrome or complication never materialized in influenza-like epidemics. But if so, what does the encephalitis lethargica epidemic, long considered an unexplained flu encephalitis (Grippe-Enzephalitis), tell us about the neurologic manifestations in the early and late phases? Can we expect to see long-term effects with pandemics? Second, could the injury to the nervous system be a consequence of ineffective treatment (i.e., refractory hypoxemia despite all available options) or a result of multi organ failure which may include disseminated intravascular coagulation? Third, what was the experience with the mass use of new vaccines? Such additional

\section{Springer}


knowledge will be useful for the neurointensivist for when the next domino falls.

\section{The Respiratory Virus can be Directly Neurotropic}

Influenza virus has been detected occasionally by virus isolation or nested RT-PCR in CSF of patients and in brain autopsies [3, 4]. Viruses can directly hit the brain or ravage the spinal cord. The A/VN/1203/04 H5N1 influenza strain preferentially targets the basal ganglia but also affects the brainstem and midbrain, which have the locus ceruleus and substantia nigra, structures that degenerate in Parkinson's disease [5]. The Japanese experience in the H1N1 global pandemic of 2009 included descriptions of necrotic encephalopathy in children preferentially affecting the thalami [6]. But one of the more singular disorders is encephalitis lethargica, pandemic through 1918, both in Europe and the USA, which was first reported by Von Economo [7] (Fig. 1). The syndrome was seen as early as 1916 , well before the Spanish flu pandemic emerged. One thing it taught us was that stupor could be caused through thalamomesencephalic lesions (necrosis and perivascular lymphocytic infiltrate)

\section{Wiener klinische Wochenschrift}

Begründet von weil. Hofrat Prof. H. v. Bamberger

Herausgegeben von

O. Chiari, P. Chvostek, P. Dimmer, V. R. v, Ebner, A. Prelh. v. Eiselsberg, S. Exner, B, Finger, Alexander Fraenkel, Errat Fuchs, M. v. Gruber, lulius v. Hochenegg, F. Hochstetter, A. Kolisko, H. Meyer, J. Moeller, H. Obersteiner, Richard Daltauf, A. Politzer, Clemens Freih. v. Pirquet, Gustav Riehl, J. Schaffer, A. Schattenfroh, F. Schauta, I. Tandler, C. Toldt, I. v. Wagner, Anton Weichselbaum und E. Wertheim

Organ der k. k. Gesellschaft der Aorzto in Wien Redigiert von Prof. Dr. Alexander Fraenkel

Verlag von Wilhelm Braumüller, k. k. Universitäts-Verlagsbuchhandlung, Gesellschaft m. b. H., VuII/1, Wickienburgoasse 13. Telephon 17.618.

\begin{tabular}{lll}
\hline XXX. Jahrg. Wien, 10. Mai 1917 & Nr. 19 \\
\hline
\end{tabular}

INBALT:

1. Originalartikel: 1 . Aus der psychiatrischen Klinik in Wien. (Vorstand Hofr. Prof. J. Wagner v. Jauregg.) Encephalitis
lethargica. Von Priv.-Doz. C. v. E E o n o mo, Assistent der
Klinik S. 581 .

2. Aus der k. u. k. II. mobilen Chiurgengruppe der Klinik von Eiselsberg. (Kommandant: Reg.-Arzt Dr. Johann Philipowicz.) Ueber Komplikationen bei Lungensehüssen, Ursachen des fieberhaften Haemothorax und der Empyembildung. Von Reg-
Arzt Dr. J. P hili $\mathrm{p}$ ow $\mathrm{i} \mathrm{c} z$, a. e. Assistent der Klinik Kuttner,
fruher Operateur der Klinik von Eiselsberg. S. 585 . 3. Aus dem Lazarett towarnoi Kontori in Pensa (RuBland). Be-
obachtungen an Hemeralopie- und Skorbutkranken. Von Priv.-
Doz. Dr. Emil Z a k, Wien. S. 592 .

4. Aus dem Laboratorium der Ludwig Spiegler-Stiftung in Wien. Vorstand: Prof. Dr. Sigmund Fränkel,
Verminderung des Rhodangehaltes im Speichel bei Syphilis. Von Franz Peter. S. 595.

Aus der psychiatrischen Klinik in Wien. (Vorstand: psychiatrischen Klinik in Wien. (V
Hofrat Prof. J. Wagnex v. Jauregg.) Encephalitis lethargica. Von Priv.-Doz. C. v. Economo, Asssistent der Klinik.

Seit Weihnachten hatten wir an der psychiatrische Klinik Gelegenheit, eine Reihe von Fällen zu beobachten, die keiner unserer gebräuchlichen Diagnosen entsprechen, untereinander jedoch eine gewisse Aehnlichkeit in ihrer Entstehungsart und Symptomatołngie bieten, die dazu drängt, sie zu einem Krankheitsbilde zusammenzufassen. Es handelt sich, wenn ich so sagen darf, um eine Art S chlafkrankheit von zwar meist schleppendem Verlauf, deren erste Symptome aber gewolnlich akut mil Koplschmerzen

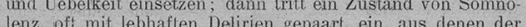
lenz, oft mit lebhatten Delirien gepaart, ein, aus denen der Auskunft träge korrekt zu befolgen, zul gehen und stehen vermag sich selbst überlassen aber wieder in seinen Schlummerzustand verfält. Diese deliröse Simnotenz kann nun progressiv, rapid oder im Laufe einiger Wochen zum Tode führen oder aber sie dauert mit stundenweisen, tagweisen oder noch größeren Schwankungsampli ü̈den der Tiefe der Bewußtseinstrübung, welche von einfacher Schlärrigkeit bis zum tiefsten Sopor und Koma gehen kann, wochenlang, ja monatelang unverandert an oder aber 'ss tritt allmählich eine Besserung ein, die Patienten sind aber danm noch lange psychisch geSchlafsüchtigkeit bestand, kann dieselbe bald schwinden,

5. Aus dem pathologischen Institate des städtischen Krankenrico Ferrari. Die Bruck'sche Syphilisreaktion. Von cand. med. Lorenzo Lo o r o n-
zu tti, derzeit Assistent am Institute. S. 596 . II. Referate: Die Nebennierenrinde. Von Max La nd a u $f$. Allgemeine Bakteriologie und Sterilisationslehre fur Aerzte und
Pharmazeuten. Von Dr. K. Lanbenheimer. Ref.. Joannovic s. III. Aus versehiodenen Zeitschriften.

IV. Vermischte Nachrichten.

V. Verhandlungen ärztlicherGesellschaften und Kongresberichte. VI. Nilitïrsanitätswesen. Aus dem orthopädischen Spitale in Zagreb Von Abt.-Chefarzt, Ldst.-Oberarzt Dr. J. Milič ic, Zivilarzt in split, Dalmation. IX. Demonstrationsabend im $k$. u. $k$.

so daß eventuell bestehende Lähmurngserscheinum, die wir gleich später bestehende Lahmungserscheinungen, die

Gleich zu Beginn, in den ersten Tagen der Erkran kung schon, stellen sich einzelne meningeale Reizsymptome, doch niemals in sehr ausgeprägter Weise ein (eine geringe Nackensteifigkeit oder blois Druckempfindlichkeit des Nackens, Klopfempfindlichkeit des Schädels, Druckempfindkeit der Bulbi, nur selten eine Andeutung von Kernig) Die Krankheit kann unter Fiebererscheinungen und ganz fieberlos verlaufen. tinen bestimmten Typus weis die Temperatur micht auf. Das eventuelle Auftreten de Hebers und seine Intensitat scheint von keiner Wirkun

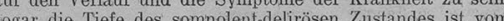
sogar die Thefe des somnoient-delirosen Zustandes ist vom tientin gesehen, die im Aumenblicke, da sie einmal fieberfre war lebhafter delirierte als vorher. $\mathrm{Zu}$ den allgemeinen Symptomen gesellen sich in der Regel auch Lähmungserscheinungen, sowohl im Gebiete de Hirnnerven, als auch der Extremitäten. Besonders die Augenmuskeln sind oft befallen. Die leichte Ptosis, die noch als physiologische Lidschwere der. Somnolenz gedeutet werden kann und die noch durch eine energische Anstrengung de Patienten überwunden wird, geht allmählich in eine paracysche Plosis uber, or verbuaden Auch Paresen der anderen Augenmuskelnerven kommen vor, ebenso wie Paresen sanstiger Hirnnerven und Lähmungen der Extremitäten mit Reflexstörungen. Die Augenmuskel störungen können auch als erstes Symptom das Krank

Fig. 1 Cover page on Baron Von Economo's seminal paper 
and, in some patients, hypothalamic involvement. In its acute presentation, patients experienced a gradual onset of nondescript flu-like symptoms, malaise, low-grade fever, pharyngitis, shivering, headache, vertigo, and vomiting. Respiratory symptoms occurred but were more likely central rhythm abnormalities and not from upper respiratory catarrh. Severity varied, but the "somnolentophthalmoplegic" form or oculomotor cranial nerve palsies alone were most common as well as involuntary forced eye movements (oculogyric crises, Fig. 2). Postencephalitic parkinsonism presented with catatonia. The proportion of patients who developed this postencephalitic catatonic stupor was comparatively small, although hundreds of descriptions exist (certainly not the millions claimed by Oliver Sacks in his book Awakenings.) The manifestations occurred after an interval, even years after the infection, and, in over $75 \%$ of the survivors, in 5-10 years. The quasi-temporal relationship with the 1918 Spanish flu epidemic suggested an association, but without a clear etiological argument for or against, the relationship remains questionable $[8,9]$. Vilensky who had access to patient material concluded, "although the findings in the majority of studies refute the influenza hypothesis, this etiology would provide a convenient explanation for the disappearance of encephalitis lethargica because the influenza strains that caused the 1918 influenza epidemic left human circulation sometime before 1933" [9]. Some still attributed the cause of this disorder to a flu variant (Kopfgrippe), but the cause remains a mystery. Foley, who studied the disorder in great historical detail, stoutly denied any connection [8].

\section{The Nervous System may be an Innocent Bystander}

Already in the early 1900s, autopsies from patients who succumbed during major influenza epidemics showed mostly secondary effects of hypoxemia, shock, or the consequences of secondary bacterial pneumonia leading to bacterial meningitis. Some reported "neurologic and mental disturbances" and coma, leading to the umbrella term "influenza encephalitis" [10]. Few studies published autopsy details on brain cutting but reported a "hemorrhagic encephalitis" (Fig. 3) [11]: The cut surfaces of the brain in practically every instance presented an excessive number of bleeding points. They were most pronounced in the white matter of the hemispheres, but occasionally the corpus thalamus was especially involved ..."Microscopically, intense congestion of the vessels and numerous minute hemorrhagic foci were encountered." (Furthermore, "the brain was generally congested, [with] hyperemia and focal hemorrhages being very frequent... The changes were more marked in the cerebrum, while the cerebellum, medulla, pons, and spinal cord showed relatively slight alterations....

\section{a}

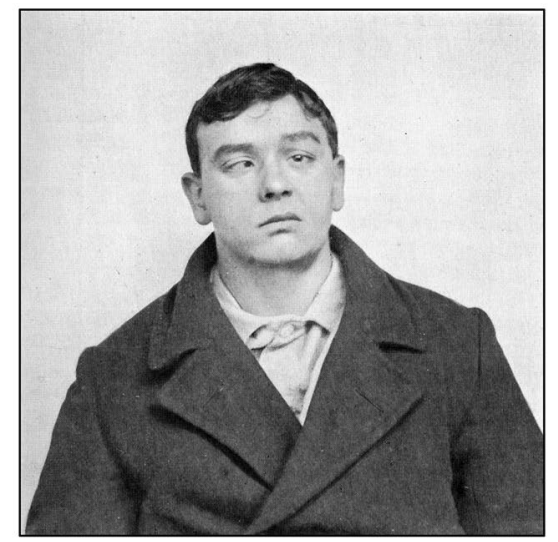

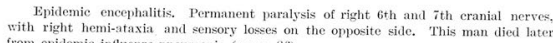

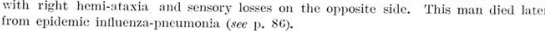

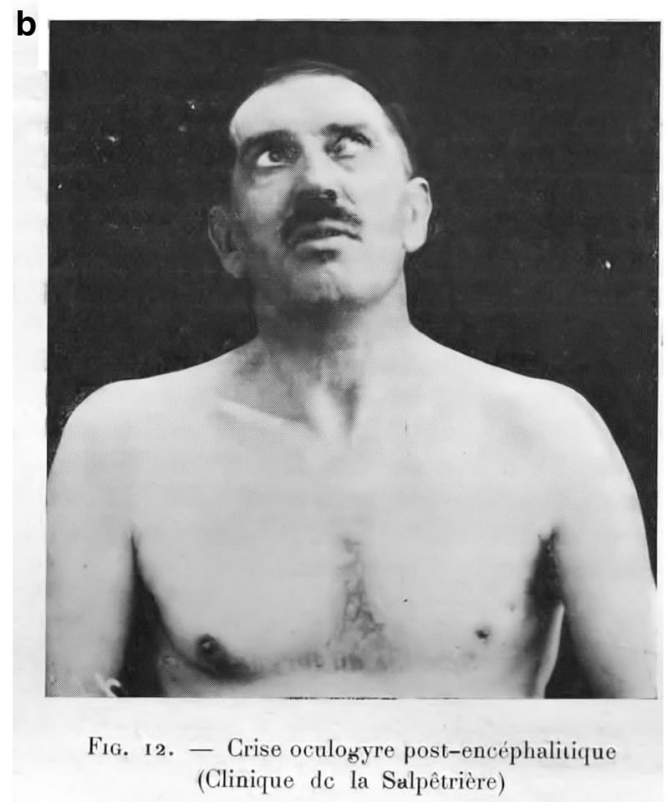

Fig. 2 Patients with Encephalitis lethargica. Cranial nerve deficits (a) and oculogyric crisis (b) (forced upward deviation of the eyes that may persist for hours (kindly provided by Dr Olivier Walusinki)

"Suppurative meningitis, due to secondary invaders, was present in 20 per cent.") In autopsies performed during the 1957 Asian Flu pandemic, "convulsive seizures and coma" were noted "without localizing signs occurring after several days of mild respiratory symptoms" [12]. Grossly, the brain showed severe diffuse swelling but without inflammatory cell infiltrate. The coroners from the greater Cleveland area concluded, "In none of the cases reported in the literature or in this series are there any changes that satisfy the criteria for 


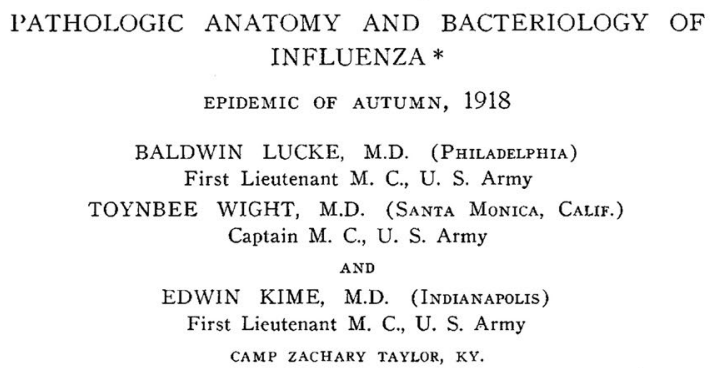

In this paper the results of our studies on the pathologic anatomy and bacteriology of influenza during the epidemic of the fall of 1918 at Camp Zachary Taylor and Camp Knox, Kentucky, are prescnted.

Necropsies, with routine bacteriologic cultures, were performed throughout the entire epidemic, so that a fairly definite picture of its various stages could be formed. The present investigation has been limited to 126 definitely proven fatal cases of influenza. These were selected from a considerably larger number by ruling out all patients who clinically gave evidence of preexisting disease, such as tuberculosis, measles, etc., or where such evidence was found at the necropsies. Thus the morbid changes encountered may be looked on as primarily representing the end-results of the virus of influenza and its commensals.

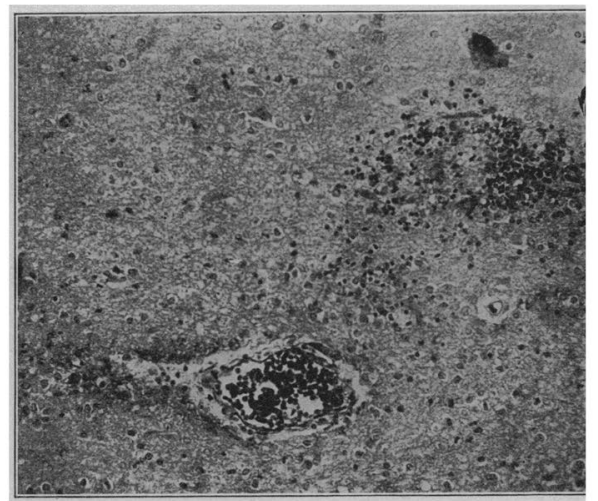

Fig. 37.- (Cerebrum.) Focal hemorrhages and congestion. Note area of

hemorrhage in upper right part of photograph.

Fig. 3 Autopsy series in Influenza pandemic. Microhemorrhages in the brain were commonly detected

a diagnosis of encephalitis." The manner in which the nervous system was involved remained unknown.

Acceptable documentation in a handful of cases of the largest SARS experience in Taiwan showed ischemic strokes associated with marked hypotension and hypercoagulability-another indication there might be secondary injury. Steroid rhabdomyolysis and neuromuscular junction blocker-associated critical illness polyneuropathy were also noted [13]. With these cases, caution was exercised in attributing the virus to a direct attack on the peripheral nerves because other, more plausible reasons existed [14].

\section{New Vaccines to Manage Pandemics may be Harmful}

Long forgotten but deserving of mention is a major polio vaccine disaster that occurred in the wake of Salk's discovery. Right after the Pittsburgh Press proclaimed on April 12, 1955, "Polio is Conquered" and the uniform "canonization of Jonas Salk" [15], patients contracted poliomyelitis soon after receiving a vaccine from Cutter Laboratories of Berkeley, California. Instead of an inactivated virus, the vaccine contained live polio virus. Failure to ensure the inactivation process (also summarized as "multiple synergistic failures") led to a resurgence of cases 
[16]. While paralysis was often limited to the limb receiving the injection, it still caused deaths. Over 200 cases of paralytic illness occurred before it was withdrawn from the market. Although the company was not found liable, the episode led to federal regulation of vaccines.

The Swine Flu (Influenza A) mass vaccination in 1976 (in which President Ford proclaimed that "every man, woman and child "had to be vaccinated to protect us from the upcoming "killer flu") led to an outbreak of Guillain-Barré syndrome (GBS). Over a thousand cases were certified with the $C D C$, but later review of some states' records found considerable numbers of misdiagnoses. Nonetheless, the association remained, and the excess cases of GBS during the first 6 weeks were attributed to the vaccine (8.6 per million vaccines in Michigan and 9.7 per million vaccines in Minnesota) [17].

\section{Conclusion}

Neurointensivists are forewarned and may be the first ones encountering patients seriously affected by pandemics causes by respiratory viruses. Editors of journals may be forewarned too [18]. With any new pandemic, new neurologic observations appear rapidly, and there is a rush to publish, but cases clouded by ambivalent evidence may not show the necessary reservation in claiming causality $[19,20]$. Some associations are entirely expected [21]. With the recent SARS-COVID-19, we can expect reports of a number of associated neurologic illnesses, some that have been seen previously-but more incidentally-in unusual respiratory viral outbreaks with unusual viruses and not necessarily pandemics. Undoubtedly, respiratory viruses damage the central and peripheral nervous system, but other (patient or iatrogenic) factors may play a role. New inactivated live vaccines are not innocuous and may cause serious side effects if poorly manufactured or inadequately tested.

The direct effects of respiratory viruses have been largely unexplained, are nonspecific, and perhaps were limited to the sickest patient. The brain swelling without evidence of anoxic injury in many patients in the Asian flu epidemic has not been explained. (Reye's syndrome comes to mind, particularly in an era when Bayer's aspirin was manufactured worldwide.) Whether the endothelial damage in many organ systems may affect the brain vasculature or if it is a coagulopathy which causes strokes in SARS-COVID-19 remains to be seen [22]. With our current pandemic, we may see later neurologic manifestations if encephalitis lethargica is a model.

However, all of this goes to show that the circumstances are different with any new contagion and outcomes are not a given. The historical medical record is full of unsubstantiated analogies, and after our current contagion, we will find out whether the virus is neurologically unexceptional, unique, and targeted, or if it produces secondary manifestations-the unsatisfactorily termed "multifactorial encephalopathies"-only to disappear with recovery or leave long-lasting cognitive impairment from coagulation-induced strokes or anoxic-ischemic damage. Modern critical care of ventilated patients may come with a potent anesthetics, corticosteroids, opioids, and neuromuscular junction blockers which can lead to severe neuromyopathies.

Adjustment of associations (and often a full order of magnitude) is needed in medicine when new data appear. The past should warn us that we may merge too many connections in a convenient causative chain with diagnoses that are incorrect, overestimated, or underestimated. Time (and scientific scrutiny) will tell if neurointensivists can be useful "on the frontlines" [23] or will be left waiting for what is to come, without knowing what "it" is, or even finding out that "it" never occurred. If any, this new pandemic will teach us something and perhaps more than something.

\section{Conflict of interest}

The author declare that they have no conflict of interest.

\section{Publisher's Note}

Springer Nature remains neutral with regard to jurisdictional claims in published maps and institutional affiliations.

Springer Nature or its licensor (e.g. a society or other partner) holds exclusive rights to this article under a publishing agreement with the author(s) or other rightsholder(s); author self-archiving of the accepted manuscript version of this article is solely governed by the terms of such publishing agreement and applicable law.

Published online: 12 May 2020

\section{References}

1. Ibsen B. The anaesthetist's viewpoint on the treatment of respiratory complications in poliomyelitis during the epidemic in Copenhagen, 1952. Proc R Soc Med. 1954;47(1):72-4.

2. Lassen HC. A preliminary report on the 1952 epidemic of poliomyelitis in Copenhagen with special reference to the treatment of acute respiratory insufficiency. Lancet. 1953;1(6749):37-41.

3. Arbour N, Day R, Newcombe J, Talbot PJ. Neuroinvasion by human respiratory coronaviruses. J Virol. 2000;74(19):8913-21.

4. Fujimoto S, Kobayashi M, Uemura O, et al. PCR on cerebrospinal fluid to show influenza-associated acute encephalopathy or encephalitis. Lancet. 1998;352(9131):873-5.

5. Jang H, Boltz D, McClaren J, et al. Inflammatory effects of highly pathogenic $\mathrm{H} 5 \mathrm{~N} 1$ influenza virus infection in the CNS of mice. J Neurosci. 2012;32(5):1545-59.

6. Morishima T, Togashi T, Yokota S, et al. Encephalitis and encephalopathy associated with an influenza epidemic in Japan. Clin Infect Dis. 2002;35(5):512-7.

7. von Economo C. Encephalitis lethargica. Wien Klin Wochenschr. 1917;30:581-5.

8. Foley PB. Encephalitis lethargica: the mind and brain virus. New York: Springer; 2018. 
9. Vilensky JA. Encephalitis lethargica: during and after the epidemic. New York: Oxford University Press; 2010.

10. Jelliffe S. Nervous and mental disturbances of influenza. NY Med J. 1918;108:725-8.

11. Lucke B, Wight T, Kime E. Pathologic Anatomy and Bacteriology of Influenza: epidemic of Autumn, 1918. Arch Intern Med. 1919;24(2):154-237.

12. Oseasohn R, Adelson L, Kaji M. Clinicopathologic study of thirty-three fatal cases of Asian influenza. N Engl J Med. 1959;260(11):509-18.

13. Tsai LK, Hsieh ST, Chang YC. Neurological manifestations in severe acute respiratory syndrome. Acta Neurol Taiwan. 2005;14(3):113-9.

14. Zochodne DW. SARS, SIRS, and neurological disease. Arch Neurol. 2004;61(11):1647-8.

15. Oshinsky DM. Polio: an American story. New York: Oxford University Press; 2005

16. Offit PA, Cutter The. Incident: how America's first polio vaccine led to the growing vaccine crisis. New Haven: Yale University Press; 2005.

17. SafranekTJ, Lawrence DN, Kurland LT, et al. Reassessment of the association between Guillain-Barre syndrome and receipt of swine influenza vaccine in 1976-1977: results of a two-state study. Expert neurology group. Am J Epidemiol. 1991;133(9):940-51.

18. Bauchner H, Golub RM, Zylke J. Editorial concern-possible reporting of the same patients with COVID-19 in different reports. JAMA. 2020;323:1256

19. Moriguchi T, Harii N, Goto J et al., A first case of meningitis/encephalitis associated with SARS-coronavirus-2. Int J Infect Dis. 2020.

20. Zhao H, Shen D, Zhou H, Liu J, Chen S, Guillain-Barre syndrome associated with SARS-CoV-2 infection: causality or coincidence? Lancet Neurol. 2020.

21. Toscano G, Palmerini F, Ravaglia S et al., Guillain-Barré syndrome associated with SARS-CoV-2. N Engl J Med. 2020.

22. Oxley TJ, Mocco J, Majidi S et al., Large-vessel stroke as a presenting feature of Covid-19 in the young. N Engl J Med. 2020

23. Pleasure SJ, Green AJ, Josephson SA, The spectrum of neurologic disease in the severe acute respiratory syndrome coronavirus 2 pandemic infection: neurologists move to the frontlines. JAMA Neurol. 2020. 